Asy Syariyyab: Jurnal Ilmu Syari'ah dan Perbankan Islam - ISSN 2089-7227 (p) 2598-8522 (e)

Vol. 5, No. 1, Juni 2020, pp. 21 - 51

\title{
MARKETING DIGITAL WISATA PINUS ECOPARK DALAM ETIKA BISNIS ISLAM DI LAMPUNG BARAT
}

\author{
Dharma Setyawan, Fina Sundari \\ IAIN Metro \\ Email: dharmasetyawan405@gmail.com \\ Email: : finasundari03@gmail.com
}

\begin{abstract}
This study aims to find out about the tourism development promotion strategy implemented by Pinus Ecopark Tourism through social media in the perspective of Islamic business ethics. The type of this study is a field research, with a descriptive qualitative method. The data collection techniques used were interviews, observation and documentation. The data were then analyzed inductively. The findings of the study suggested that the Pinus Ecopark Tourism used advertising, personal selling, sales promotion, public relations, and direct marketing for the development promotion strategy through various promotional variables. In carrying out promotional activities, the Pinus Ecopark Tourism manager has carried out promotions in accordance with Islamic business ethics. However, there are things that have become problems and disputes that have caused misunderstandings between the tour manager and the tour visitors: there are spot image posts that have not been updated by the tour manager for a long time, so that some visitors are disappointed because there is a mismatch between the post and the reality they have encountered at place, giving rise to a misunderstanding.
\end{abstract}

Keywords: Promotion Strategy, Tourism, Islamic Business Ethics.

\begin{abstract}
Abstrak
Penelitian ini bertujuan untuk mengetahui tentang bagaimana strategi promosi pengembangan wisata Pinus Ecopark melalui media sosial dalam perspektif etika bisnis islam. Jenis penelitian ini adalah penelitian lapangan (field research), sedangkan sifat penelitian ini adalah deskriptif kualitatif dengan tehnik pengumpulan data menggunakan metode wawancara, observasi dan dokumentasi. Dan semua data-data tersebut dianalisa secara induktif.

Berdasarkan hasil penelitian, strategi promosi pengembangan Wisata Pinus Ecopark yang digunakan oleh pengelola wisata yaitu melalui berbagai variabel promosi diantaranya yaitu periklanan, penjualan personal, promosi penjualan, hubungan masyarakat, dan pemasaran
\end{abstract}


langsung. Dalam melakukan kegiatan promosi pengelola wisata pinus ecopark telah melakukan promosi sesuai dengan etika bisnis islam, namun ada hal yang menjadi permasalahan dan percekcokan yang menyebabkan kesalahpahaman diantara postingan pengelola wisata dengan pengunjung wisata, dimana postingan gambar spot foto yang sudah lama tidak di perbaharui oleh pengelola wisata, sehingga membuat beberapa pengunjung menjadi kecewa karena kesalahpahaman tersebut.

Kata kunci: : Strategi Promosi, Pariwisata, Etika Bisnis Islam.

\section{A. PENDAHULUAN}

Indonesia merupakan Negara Kepulauan yang indah dan kaya akan hasil alam dan kebudayaan, yang terdiri dari berbagai suku, budaya, ras, agama, maupun sejarah. Setiap pulau maupun daerah tentu mempunyai potensi dan keunikan masing-masing yang menarik dan dapat dikembangkan. Hal ini dapat menjadi modal pertama Indonesia untuk menjadi maju dan terlepas dari kemiskinan. Kekayaan alam dan keberagaman bangsa indonesia dapat menjadi daya tarik wisatawan baik lokal maupun asing. Dengan demikian Indonesia dapat mengembangkan kekayaan akan potensi tersebut menjadi pariwisata.

Sektor pariwisata ditetapkan sebagai sektor yang penting untuk dikembangkan secara sinergi sebagai sektor unggulan. Melalui pendekatan pariwisata berkelanjutan (sustainable tourism) perlu sinergi antara upaya pelestarian alam dan budaya beserta warisannya untuk menunjang percepatan pembangunan nasional. Pemanfaatan alam dan budaya di sektor pariwisata terus berkembang, namun besarnya potensi sumberdaya alam dan budaya yang tersebar di hampir 17 ribu pulau di Indonesia belum dimanfaatkan sesuai dengan potensi yang dimiliki masing-masing destinasi.

Pariwisata merupakan suatu usaha mencari keseimbangan dan kebahagiaan dengan lingkungan hidup dalam dimensi sosial melalui perjalanan dari satu tempat ke tempat lain yang bersifat sementara yang 
dilakukan oleh perorangan atau kelompok. Namun pariwisata tidak hanya diartikan sebagai perjalanan saja, pada hakikatnya pariwisata juga sebagai ekonomi kreatif yang merupakan salah satu wujud pemikiran, imajinasi, pengetahuan, kemauan dan kemampuan yang kreatif, yang dapat mempercepat kemajuan pembangunan ekonomi dan perkembangan dunia usaha, melalui terciptanya lapangan pekerjaan bagi diri sendiri dan orang lain secara ekonomi dengan menciptakan ide-ide kreatif dari semua potensi wisata yang ada.

Perkembangan industri pariwisata di indonesia begitu pesat. Salah satu Provinsi di Indonesia yang memiliki potensi akan pariwisata yaitu Provinsi Lampung, khususnya Kabupaten Lampung Barat yang memiliki potensi dan kekayaan alam yang begitu eksotik menjadi tujuan wisatawan, dengan berbagai destinasi pariwisata yang terus berkembang hingga saat ini. Hal ini dapat dilihat dari data kunjungan wisatawan baik nusantara maupun mancanegara. Berikut data perkembangan jumlah kunjungan wisatawan Kabupaten Lampung Barat tahun 2015 hingga tahun 2018:

Tabel 1.1 Data Kunjungan Wisatawan Nusantara dan Mancanegara di Kabupaten Lampung Barat

\begin{tabular}{|l|c|c|c|c|}
\hline \multirow{2}{*}{ Wisatawan } & \multicolumn{4}{|c|}{ Tahun } \\
\cline { 2 - 5 } & $\mathbf{2 0 1 5}$ & $\mathbf{2 0 1 6}$ & $\mathbf{2 0 1 7}$ & $\mathbf{2 0 1 8}$ \\
\hline Nusantara & 13.825 & 14.567 & 15.918 & 16.372 \\
\hline Mancanegara & 421 & 396 & 531 & 655 \\
\hline \multicolumn{1}{|c|}{ Total } & $\mathbf{1 4 . 2 4 6}$ & $\mathbf{1 4 . 9 6 3}$ & $\mathbf{1 6 . 4 4 9}$ & $\mathbf{1 7 . 0 2 7}$ \\
\hline
\end{tabular}

Sumber: Dinas Kepemudaan Olahraga dan Pariwisata Kabupaten Lampung Barat 2019.

Data diatas menunjukan peningkatan jumlah kunjungan wisatawan nusantara maupun mancanegara dari tahun ke tahun. Terlihat pada tahun 2015 jumlah kunjungan wisatawan adalah sebanyak 14.246 jiwa, pada tahun 2016 jumlah kunjungan wisatawan meningkat menjadi 14.963 jiwa, dan pada tahun 2017 jumlah kunjungan wisatawan meningkat lagi menjadi 
16.449 jiwa, selanjutnya pada tahun 2018 jumlah kunjungan wisatawan sebanyak 17.027 jiwa.

Melihat jumlah kunjungan wisatawan nusantara maupun mancanegara yang terus meningkat setiap tahunnya, Bupati Lampung Barat Bpk. Parosil Mabsus terus mendukung perkembangan pariwisata yang ada, salah satunya dengan mengadakan pembangunan, pengadaan fasilitas, perbaikan dan pengembangan wisata sebagai Centre wisata di dekat kantor pemerintahan yaitu Kebun Raya Liwa (KRL) Kabupaten Lampung Barat.

Salah satu Kecamatan yang berada di Kabupaten Lampung Barat, yang memiliki pesona alam yang sangat indah dan sangat beragam akan bentuknya yaitu Kecamatan Sumber Jaya, khususnya Desa Sukapura yang memanfaatkan Sumber Daya Alam atau Hutan Pinus untuk pembangunan wisata alam. Tempat ini dinamakan Wisata Pinus Ecopark.

Wisata Pinus Ecopark ini memiliki suasana yang asri dan sejuk, dengan pepohonan pinus yang rindang ini memberikan oksigen yang sangat baik untuk pengunjung. Bukan hanya itu, fasilitas yang tersedia di tempat wisata ini juga menjadi nilai tambah yang dapat dinikmati oleh pengujung. Dengan adanya objek-objek foto yang sangat Instagramable, Seperti Hiasan payung, Jembatan kayu, Pondokan atau Saung, Ayunan santai dan lain-lain.

Wisata Pinus Ecopark dibentuk dengan adanya kerjasama antar lembaga terkait seperti, KPHL II Liwa (Kelompok Pecinta Hutan Lindung), KPA Green (Kelompok Pecinta Alam Hijau), HPPHL (Himpunan Pemuda Peduli Hutan dan Lingkungan) serta Kelompok HKM (Hutan Kemasyarakatan) yang membentuk konsorsium yang bernama West Land. Ke-Empat lembaga tersebut secara terus menerus mengelola dan mengembangkan hutan pinus ini untuk dijadikan tempat wisata, dan mulai 
mempromosikan tempat ini melalui media sosial, dintaranya melalui Instagram, Facebook, dan Youtube.

Promosi adalah kegiatan untuk mengomunikasikan kelebihankelebihan produk kepada konsumen dan membujuknya untuk membeli, sehingga dapat memberi beberapa informasi mengenai produk atau jasa yang ditawarkan oleh perusahaan kepada konsumen (Zainal Abidin dan Hutami P. Puspitasari, 2018: 76).

Promosi melalui media sosial memiliki peranan penting dalam pengembangan wisata, karena berkaitan dengan usaha dalam mengkomunikasikan potensi wisata kepada target audien. Dengan melakukan promosi melalui media sosial diharapkan Wisata Pinus Ecopark yang ada di Kabupaten Lampung Barat dapat dikenal oleh masyarakat luas dan dapat meningkatkan jumlah pengunjung. Namun sebagai umat muslim semua bentuk kegiatan yang dilakukan haruslah sesuai dan tidak menyalahi syariat islam, begitu pula halnya promosi yang dilakukan haruslah sesuai dengan landasan etika bisnis islam.

Pada hakikatnya etika bisnis dalam islam adalah landasan perilaku manusia dalam melakukan kegiatan perniagaan atau perdagangan di kehidupan sehari-hari, dengan penerapan prinsip-prinsip ajaran islam yang bersumber pada Al-Qur'an, Hadist Nabi Muhammad SAW, Qiyas dan Ijma'. Dalam melakukan kegiatan bisnis islam yang beretika haruslah terhindar dari peraktek riba, ketidakpastian, penipuan, dan ketidakadilan, dengan berlaku jujur terhadap pembeli atas barang yang diperjual belikan dan tidak berlebih-lebihan dalam pengambilan keuntungan.

Dalam melakukan promosi Islam sangat melarang, adanya pemalsuan dan penipuan karena dapat menyebabkan kerugian dan kezhaliman serta dapat menimbulkan permusuhan dan percekcokan. Sebagaimana Allah berfirman dalam Q.S. Al-Ankabut Ayat 3 dan QS. An-Nahl ayat 105: 


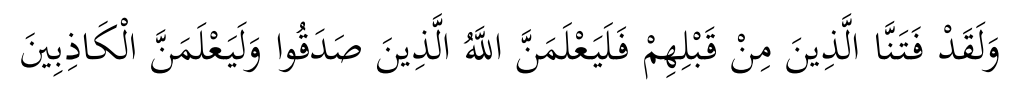

"dan Sesungguhnya Kami telah menguji orang-orang yang sebelum mereka, Maka Sesungguhnya Allah mengetahui orang-orang yang benar dan Sesungguhnya Dia mengetahui orang-orang yang dusta."

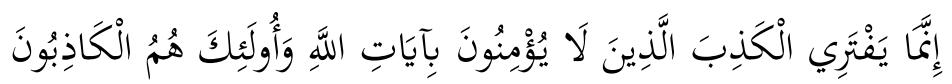

"Sesungguhnya yang mengada-adakan kebohongan, hanyalah orang-orang yang tidak beriman kepada ayat-ayat Allah, dan mereka Itulah orang-orang pendusta."

Pada dasarnya manusia diberikan kebebasan untuk mengembangkan model $\mathrm{mu}^{\prime}$ amalah. Implikasi dari kebebasan dalam hal mu'amalah adalah kebebasan dalam melakukan aktivitas ekonomi. Dimana disebutkan dalam kaidah fiqh bahwa: "Hukum dasar mu'amalah adalah diperbolehkan, sampai ada dalil yang melarangnya." (Imam Mustofa, 2016: 10)

Berdasarkan hasil prasurvey dengan 15 pengunjung wisata, lima diantaranya mengutarakan bahwa promosi yang dilakukan masih mengandung unsur penipuan yang membuat beberapa pengunjung kecewa, karena gambar yang di unggah di Instagram tidak sesuai dengan realita, bahkan beberapa spot foto yang telah di unggah sudah tidak ada lagi di lokasi. Selain itu keberadaannya masih belum banyak diketahui oleh khalayak luas, karena kurang aktifnya admin dalam melakukan promosi, baik dalam me-Repost foto, maupun mengolah kata dalam berpromosi. Padahal bila dikelola dengan baik tentu wisata tersebut memiliki potensi yang besar, mampu mengangkat ekonomi masyarakat sekitar, perbaikan lingkungan hidup, dan peningkatan ilmu pengetahuan teknologi.

Berdasarkan uraian diatas maka peneliti tertarik mengadakan penelitian dengan judul "Strategi Promosi Pengembangan Wisata Pinus Ecopark Melalui Media Sosial Dalam Perspektif Etika Bisnis Islam (Study Pada Wisata Pinus Ecopark Di Lampung Barat). 


\section{B. METODOLOGI PENELITIAN}

Jenis penelitian ini adalah penelitian lapangan (field research), yaitu terjun langsung kelapangan guna mendapatkan penelitian pada objek yang di bahas. Penelitian lapangan dilakukan dalam kancah kehidupan sebenarnya (Sutrisno Hadi, 1981: 40), dengan menggunakan pendekatan deskriptif kualitatif yaitu pengumpulan data untuk menjawab pertanyaan mengenai setatus terahir dari subjek penelitian yang tidak dapat di ukur dalam data numeric (Mudrajad Kuncoro, 2003: 8). Tehnik pengumpulan data menggunakan metode wawancara dan dokumentasi. Dan semua datadata tersebut dianalisa secara induktif.

Penelitian deskriptif bertujuan untuk menggambarkan, meringkaskan berbagai kondisi, berbagai situasi atau berbagai variabel yang timbul di masyarakat yang menjadi objek penelitian itu, kemudian menarik kepermukaan sebagai suatu ciri atau gambaran tentang kondisi tertentu (Burhan Bungin, 2013: 48).

\section{STRATEGI PROMOSI}

\section{Pengertian Strategi Promosi}

Strategi adalah suatu kesatuan rencana yang menyeluruh komprehensif, dan terpadu yang diarahkan untuk mencapai tujuan perusahaan (Nana Herdiana Abdurrahman, 2015: 197-198). Strategi bagi suatu organisasi adalah suatu cara, taktik, rencana, dan suatu proses perencanaan yang berorientasi pada masa yang akan datang baik jangka pendek maupun jangka panjang dan digunakan untuk mencapai suatu tujuan tertentu serta untuk menghadapi persaingan.

Sedangkan promosi merupakan salah satu variabel dalam bauran pemasaran, yang pada hakikatnya promosi adalah suatu kegiatan yang dilakukan oleh perusahaan untuk mengenalkan suatu produknya baik barang maupun jasa kepada konsumen, dengan maksut untuk 
mempengaruhi dan menarik perhatian konsumen, agar konsumen tertarik untuk membeli produknya.

Strategi Promotion (promosi) adalah salah satu langkah yang ada pada manajemen pemasaran yang menjadi suatu taktik atau suatu rencana yang digunakan perusahaan untuk mengenalkan produk yang dimilikinya baik berupa barang atau jasa kepada konsumen agar konsumen tertarik untuk membelinya. Kegiatan pada strategi promosi berupa komunikasi dan interaksi antara perusahaan dengan konsumen. Interaksi dalam strategi promosi berupa pemberian informasi, ajakan, dan kegiatan mempengaruhi konsumen terhadap suatu produk.

\section{Tujuan Promosi}

Suatu kegiatan promosi dilakukan tentunya memiliki tujuan tertentu. Menurut Basu Swastha, dan Irawan tujuan promosi adalah:

a. Modifikasi tingkah laku,

b. Memberi tahu,

c. Membujuk, dan

d. Mengingatkan.

Secara singkat dapat dikatakan bahwa pada dasarnya tujuan utama dari promosi adalah menginformasikan, mempengaruhi, dan membujuk konsumen agar permintaan konsumen akan barang maupun jasa terus meningkat. Selain itu juga untuk memaksimalkan kegiatan pemasaran, dan juga agar kegiatan penjualan pribadi dan periklanan terkoordinasi dengan baik.

\section{Bauran Promosi (Promotion Mix)}

Menurut Kotler \& Armstrong variabel-variabel yang ada di dalam promotional mix ada 5, yaitu:

a. Periklanan (advertising) 
b. Penjualan Personal (personal selling)

c. Promosi Penjualan (sales promotion)

d. Hubungan Masyarakat (Public relation)

e. Pemasaran Langsung (direct marketing)

Dengan demikian, bauran promosi merupakan biaya yang harus dikeluarkan sponsor (perusahaan) untuk melakukan promosi dalam rangka mensukseskan penjualan dan insentif jangka pendek, untuk membangun hubungan baik dengan publik terkait untuk memperoleh dukungan, membangun "citra perusahaan" yang baik dan komunikasi langsung dengan pelanggan yang diincar secara khusus untuk memperoleh tanggapan langsung.

\section{Promosi Melalui Media Sosial}

Dalam memperkenalkan suatu produk baik barang maupun jasa maka dibutuhkan suatu cara atau strategi yang digunakan. Salah satu strategi yang biasa digunakan dalam pemasaran yaitu promosi.

Kegiatan promosi merupakan akses komunikasi kepada masyarakat luas yang dapat dilakukan secara langsung maupun melalui media sosial. Seperti pemberian informasi dari mulut ke mulut, melalui instagram, youtube, facebook, Tweeter, dan lain-lain.

Media sosial menurut Kotler adalah media yang digunakan oleh konsumen untuk berbagi teks, gambar, suara, dan video informasi baik dengan orang lain maupun perusahaan dan sebaliknya. Dengan kharakteristik uniknya tersebut, media sosial bisa dimanfaatkan sebagai alat promosi bisnis yang efektif. Blog, Facebook, Twitter, Instagram dan Youtoube merupakan alat promosi bisnis yang dirasa cukup efektif untuk promosi yang lebih luas dan lebih efektif dibanding media konvensional seperti media cetak, brosur, dan papan baliho.

Berdasarkan uraian di atas berarti bahwa dengan munculnya media sosial yang semakin berkembang pesat segala sesuatu dapat ditangani 
dengan mudah. Penyebaran informasi juga semakin cepat, ringkas, dan sederhana. Media sosial begitu mudah digunakan, bahkan dapat digunakan oleh orang-orang pedalaman, hanya dengan menggunakan koneksi internet, Dengan jangkauan luas dan global, siapa pun bisa mengkomunikasikan informasi secara cepat tanpa hambatan geografis.

\section{KONSEP PARIWISATA}

\section{Pengertian Pariwisata}

Menurut Undang-undang RI nomor 10 tahun 2009 tentang Kepariwisataan, pengertian wisata adalah kegiatan perjalanan yang dilakukan oleh seseorang atau sekelompok orang dengan mengunjungi tempat tertentu untuk tujuan rekreasi, pengembangan pribadi, atau mempelajari keunikan daya tarik wisata yang dikunjungi, dalam jangka waktu sementara (Isdarmanto, 2017: 8).

Sedangkan definisi Pariwisata menurut (Kementerian Hukum dan Hak Asasi Manusia, 2009) adalah berbagai macam kegiatan wisata dan didukung berbagai fasilitas serta pelayanan yang disediakan oleh masyarakat, pengusaha, pemerintah, dan pemerintah daerah (Bab 1, Pasal 1, Ayat 3).

Berdasarkan beberapa pendapat diatas pariwisata merupakan suatu usaha mencari keseimbangan dan kebahagiaan dengan lingkungan hidup dalam dimensi sosial melalui perjalanan dari satu tempat ke tempat lain yang bersifat sementara yang dilakukan oleh perorangan atau kelompok. Namun pariwisata tidak hanya diartikan sebagai perjalanan saja, pada hakikatnya pariwisata juga merupakan salah satu faktor yang penting bagi pertumbuhan ekonomi, karena dengan adanya pariwisata dapat membantu masyarakat sekitar dalam menciptakan lapangan pekerjaan di area wisata. 


\section{Prinsip Pengembangan Wisata}

Sebuah destinasi dapat dikatakan akan melakukan pengembangan wisata jika sebelumnya sudah ada aktivitas wisata. Untuk dapat meningkatkan potensi pariwisatanya, yang perlu dilakukan adalah merencanakan pengembangan wisata agar dapat lebih baik dari sebelumnya. Tiga prinsip utama dalam sustainability development:

a. Ecological Sustainability, yakni memastikan bahwa pengembangan yang dilakukan sesuai dengan proses ekologi, biologi, dan keragaman sumber daya ekologi yang ada.

b. Social and Cultural Sustainability, yaitu memastikan bahwa pengembangan yang dilakukan memberi dampak positif bagi kehidupan masyarakat sekitar dan sesuai dengan kebudayaan serta nilai-nilai yang berlaku pada masyarakat tersebut.

c. Economic Sustainability, yaitu memastikan bahwa pengembangan yang dilakukan efisien secara ekonomi dan bahwa sumber daya yang digunakan dapat bertahan bagi kebutuhan di masa mendatang.

Pada hakikatnya prinsip pengembangan wisata secara berkelanjutan selalu memastikan bahwa pengembangan yang dilakukan berdasarkan perencanaan yang matang dengan tujuan yang jelas. Memastikan bahwa pengembangan yang dilakukan dapat memberikan manfaat dan memiliki nilai lebih yang dapat dirasakan oleh pengunjung wisata. Sehingga para pengunjung dan juga masyarakat sekitar memiliki kepuasan atas pengembangan yang dilakukan. Serta tidak memberikan dampak negatif bagi masyarakat maupun para pengunjung.

Pada hakikatnya prinsip pengembangan wisata secara berkelanjutan selalu memastikan bahwa pengembangan yang dilakukan berdasarkan perencanaan yang matang dengan tujuan yang jelas. Memastikan bahwa pengembangan yang dilakukan dapat memberikan 
manfaat dan memiliki nilai lebih yang dapat dirasakan oleh pengunjung wisata. Sehingga para pengunjung dan juga masyarakat sekitar memiliki kepuasan atas pengembangan yang dilakukan. Serta tidak memberikan dampak negatif bagi masyarakat maupun para pengunjung.

\section{Tujuan Pengembangan Wisata}

Menurut Undang-undang Republik Indonesia Nomor 10 tahun 2009 pasal 4 tentang Kepariwisataan, kepariwisataan bertujuan untuk:

a. Meningkatkan pertumbuhan ekonomi;

b. Meningkatkan kesejahteraan rakyat;

c. Menghapus kemiskinan;

d. Mengatasi pengangguran;

e. Melestarikan alam, lingkungan, dan sumber daya;

f. Memajukan kebudayaan;

g. Mengangkat citra bangsa;

h. Memupuk rasa cinta tanah air;

i. Memperkukuh jati diri dan kesatuan bangsa; dan

j. Mempererat persahabatan antarbangsa.

Berdasarkan tujuan pengembangan kepariwisataan diatas pada dasarnya pengembangan pariwisata bertujuan untuk menarik dan mendatangkan wisatawan, dengan memberikan kepuasan pelayanan agar lebih banyak yang berkunjung, sehingga dapat meningkatkan pertumbuhan ekonomi, mensejahterakan masyarakat, mengurangi pengangguran serta melestarikan alam.

\section{Strategi Pengembangan Wisata}

Strategi pengembangan wisata adalah suatu taktik atau cara yang digunakan untuk pengembangan wisata dengan cara memperbaiki dan meningkatkan wisata yang telah ada melalui sarana dan prasarana 
seperti pelayanan, rumah makan, hiburan, tempat penginapan, spot foto dan lainnya.

Menurut Joyosuharto, pengembangan pariwisata memiliki tiga fungsi yaitu:
a. menggalakkan ekonomi
b. memelihara kepribadian bangsa \& kelestarian fungsi dan mutu lingkungan hidup
c. memupuk rasa cinta tanah air dan bangsa.

\section{Pariwisata Sebagai Ekonomi Kreatif}

Di dalam pengembangan pariwisata tidaklah mudah, dibutuhkan inovasi-inovasi yang tinggi serta kreatifitas yang menarik, agar mampu menyerap wisatawan, baik wisatawan mancanegara maupun wisatawan domestik.

Departemen Perdagangan Republik Indonesia merumuskan ekonomi kreatif sebagai upaya pembangunan ekonomi secara berkelanjutan melalui kreativitas dengan iklim perekonomian yang berdaya saing dan memiliki cadangan sumber daya yang terbarukan. Definisi yang lebih jelas disampaikan oleh UNDP yang merumuskan bahwa ekonomi kreatif merupakan bagian integratif dari pengetahuan yang bersifat inovatif, pemanfaatan teknologi secara kreatif, dan budaya.

Saat ini, pengembangan ekonomi kreatif di Indonesia difokuskan kepada 16 subsektor, sesuai dengan Perpres Nomor 72 Tahun 2015 tentang Perubahan Atas Peraturan Presiden Nomor 6 Tahun 2015 Tentang Badan Ekonomi Kreatif. Perpres ini telah mengklasifikasi ulang sub-sektor industri kreatif dari 15 sub-sektor menjadi 16 sub-sektor, yaitu kuliner, arsitektur, disain produk, disain interior, disain grafis, film, animasi dan video, musik, fesyen, seni pertunjukan, games dan 
aplikasi, kriya, radio dan televisi, seni rupa, periklanan, fotografi, serta penerbitan.

Pada hakikatnya pariwisata sebagai ekonomi kreatif merupakan salah satu wujud pemikiran, imajinasi, pengetahuan, kemauan dan kemampuan yang kreatif, yang dapat mempercepat kemajuan pembangunan ekonomi dan perkembangan dunia usaha, melalui terciptanya lapangan pekerjaan bagi diri sendiri dan orang lain secara ekonomi dengan menciptakan ide-ide kreatif dari semua potensi wisata yang ada.

\section{E. KONSEP ETIKA BISNIS ISLAM}

\section{Etika Bisnis Islam}

Secara etimologi (ilmu asal-usul kata), "etika" berasal dari bahasa yunani "ethos" yang berarti watak kesusilaan atau adat. Dalam Kamus Umum Bahasa Indonesia, etika diartikan ilmu pengetahuan tentang asasasas akhlak (moral) (Abuddin Nata, 2015: 75).

Sedangkan bisnis islam adalah serangkaian aktivitas bisnis dalam berbagai bentuknya yang tidak dibataasi jumlah (kuantitas) kepemilikan hartanya (barang atau jasa) termasuk profitnya, namun dibatasi dalam perolehan dan pendayagunaan hartanya (ada aturan halal atau haram). Hadimulyo berpendapat bahwa etika bisnis dalam perspektif islam adalah penerapan prinsip-prinsip ajaran islam yang bersumber pada AlQur'an dan Sunnah Nabi dalam dunia bisnis. Rasulullah telah memberikan contoh dalam bermuamalah yaitu "kita harus terhindar dari unsur yang tidak dapat ridha dari Allah yaitu:
a. Harus terlepas dari unsur riba
b. Harus terlepas dari Unsur ketidakpastian
c. Harus terlepas dari Unsur penipuan dan ketidakadilan. 


\section{Prinsip Etika Bisnis Islam}

\section{a. Keesaan (Tauhid)}

Tauhid adalah mengesakan Allah, berserah diri kepada Allah, dan menjalankan segala perintah Allah serta menjauhi larangan Allah. Manusia sebagai khalifah di bumi diberikan kebebasan dalam melakukan segala sesuatu, maka segala sesuatu yang dilakukan memiliki batasan-batasan dan selalu berhubungan dengan Allah. Karena Allah yang telah menciptakan langit dan bumi beserta isinya, dan tidak ada yang patut disembah kecuali Allah.

\section{b. Keseimbangan (Adil)}

Pada dataran ekonomi, konsep keseimbangan menentukan konfigurasi aktivitas-aktivitas distribusi, konsumsi, serta produksi yang terbaik, dengan pemahaman yang jelas bahwa kebutuhan seluruh anggota masyarakat yang kurang beruntung dalam masyarakat islam didahulukan atas sumber daya riil masyarakat. Tidak terciptanya keseimbangan sama halnya dengan terjadinya kedhaliman. Hal ini berarti bahwa setiap kegiatan yang dilakukan baik dalam bidang ekonomi, bisnis, ataupun yang lainnya, harus dilakukan secara seimbang dan adil terhadap semua pihak, baik yang terlibat secara langsung maupun tidak langsung. Agar semua pihak mendapatkan hak dan kewajibannya secara adil, dan tidak ada yang terdhalimi.

\section{c. Kehendak Bebas (Free Will)}

Kebebasan merupakan bagian penting dalam nilai etika bisnis islam, tetapi dalam ajaran islam yang dimaksut dengan kebebasan adalah kebebasan yang bertanggung jawab dan tidak merugikan orang lain. Dimana segala sesuatu dalam islam selalu berdasarkan ketentuan Allah dan Rasul yang ada pada Al-Quran dan As-Sunah. 


\section{d. Tanggung Jawab (Responsibility)}

Tanggung jawab secara etika bisnis islam adalah perilaku seseorang dalam melakukan aktivitas bisnis dengan penuh rasa tanggung jawab dimana ia selalu merasa bahwa dirinya selalu diawasi oleh Allah dalam melakukan segala aktivitasnya, dan selalu memiliki rasa bahwa usaha yang dilakukan sekarang, kelak akan dimintai pertanggung jawaban diakhirat, apakah usaha yang dilakukan baik atau tidak, merugikan oranglain atau tidak, serta memberikan informasi secara benar atau tidak, dan mengandung unsur penipuan atau tidak.

\section{e. Kejujuran}

Kejujuran merupakan sifat dari pelaku bisnis yang harus ada dan harus dimiliki, karena sifat jujur merupakan kunci utama untuk mendapatkan kepercayaan dari orang lain. Kejujuran juga berkaitan dengan Tauhid, dengan keadilan, dengan kebebasan berkehendak, dan berkaitan dengan tanggung jawab. Ketika pelaku bisnis tidak memiliki sifat jujur maka sama saja ia tidak mengesakan Allah, tidak berbuat adil, memilih kehendak yang salah, sehingga ia harus mempertanggungjawabkan ketidakjujurannya terhadap Allah kelak di Akhirat.

\section{Promosi Perspektif Etika Bisnis Islam}

Islam menekankan pentingnya penerapan etika bisnis Islami bagi marketer/pemasar muslim dalam kegiatan promosinya, sebagaimana Rasulullah SAW menerapkannya ketika beliau melakukan aktivitas dagang. Di antara perilaku beliau harus menjadi patokan bagi para marketer/pemasar muslim lainnya dalam melakukan bauran promosi di antaranya: 
a. Kejujuran dan tidak menyembunyikan cacat produk .Kejujuran dalam promosi terkait dengan informasi produk sangatlah penting untuk disampaikan secara jelas. Agar tidak menimbulkan kesalahpahaman yang menyebabkan permusuhan dan percekcokan antar sesama.

b. Bersumpah Palsu. Bersumpah palsu seringkali dilakukan oleh para marketer demi untuk menarik konsumen agar membeli produknya, baik dalam bentuk periklanan, promosi penjualan maupun oleh wiraniaga (Muhammad Djakfar, 2012: 168-169).

c. Tidak menjelek-jelekkan atau menjatuhkan produk saingan Dalam konsep Etika bisnis Islam, tidak mengenal adanya persaingan yang cenderung menjatuhkan, melainkan saling bersinergi dan bekerjasama. Beragamnya produk dari produsen yang berbeda, dapat memberi kemudahan alternatif bagi konsumen untuk memperoleh produk sesuai dengan kebutuhan dan kemampuannya.

Pada hakikatnya promosi dalam perspektif etika bisnis islam adalah kegiatan promosi yang berlandaskan pada Al-Qur'an dan AsSunnah. Sehingga kegiatan promosi yang dilakukan dapat membawa keberkahan di dunia dan akhirat. Karena berbisnis bukan hanya mencari keuntungan, tetapi itu harus diniatkan sebagai ibadah kita kepada Allah SWT, dengan menerapkan prinsip-prinsip etika bisnis islam.

\section{F. STRATEGI PROMOSI YANG DIGUNAKAN PENGELOLA WISATA PINUS ECOPARK}

Strategi promosi adalah salah satu langkah yang ada pada manajemen pemasaran yang menjadi suatu taktik atau suatu rencana yang digunakan perusahaan untuk mengenalkan produk yang dimilikinya baik berupa barang atau jasa kepada konsumen agar konsumen tertarik untuk 
membelinya. Kegiatan pada strategi promosi berupa komunikasi dan interaksi antara perusahaan dengan konsumen. Tujuan utama dari promosi adalah menginformasikan, mempengaruhi, dan membujuk konsumen agar permintaan konsumen akan barang maupun jasa terus meningkat. Selain itu juga untuk memaksimalkan kegiatan pemasaran, dan juga agar kegiatan penjualan pribadi dan periklanan terkoordinasi dengan baik.

Penelitian ini dilakukan di Wisata Pinus Ecopark, Desa Sukapura, Kecamatan Sumber Jaya, Kabupaten Lampung Barat, yang mayoritas masyarakatnya beragama Islam sehingga tidak sedikit masyarakat yang telah mengetahui konsep etika bisnis islam dalam melakukan kegiatan ekonomi atau bermuamalah, khususnya dalam melakukan kegiatan promosi, baik promosi melalui media sosial maupun promosi yang dilakukan secara langsung.

Dalam penelitian ini peneliti mengadakan wawancara dengan Pengelola Wisata Pinus Ecopark, Dalam hal ini Pengelola Wisata Pinus Ecopark menggunakan beberapa variabel promotional mix, sebagai berikut:

a. Periklanan (advertising)

Periklanan merupakan bentuk komunikasi non personal yang dilakukan oleh pengelola wisata untuk menyampaikan informasi, membujuk, dan mempengaruhi konsumen agar tertarik untuk berkunjung ke lokasi wisata. Dalam hal ini pengelola wisata Pinus Ecopark menggunakan beberapa media untuk melakukan promosi seperti, media sosial diantaranya yaitu facebook, Instagram, Youtube, dan Google. Dan juga menggunakan media cetak seperti buku-buku wisata yang diterbitkan oleh Dinas Kepemudaan Olahraga dan Pariwisata Lampung Barat, dan juga Banner yang di pajang di area Wisata Pinus Ecopark. Serta melalui media elektronik seperti Rajawali TV (RTV), TVRI 
Lampung, Indosiar, dan juga Lampung TV (Asep Ketua Area, Wawancara (Sukapura: 23 November, 2019)).

Berikut gambar akun-akun media sosial yang digunakan oleh pengelola wisata Pinus Ecopark dalam melakukan promosi:

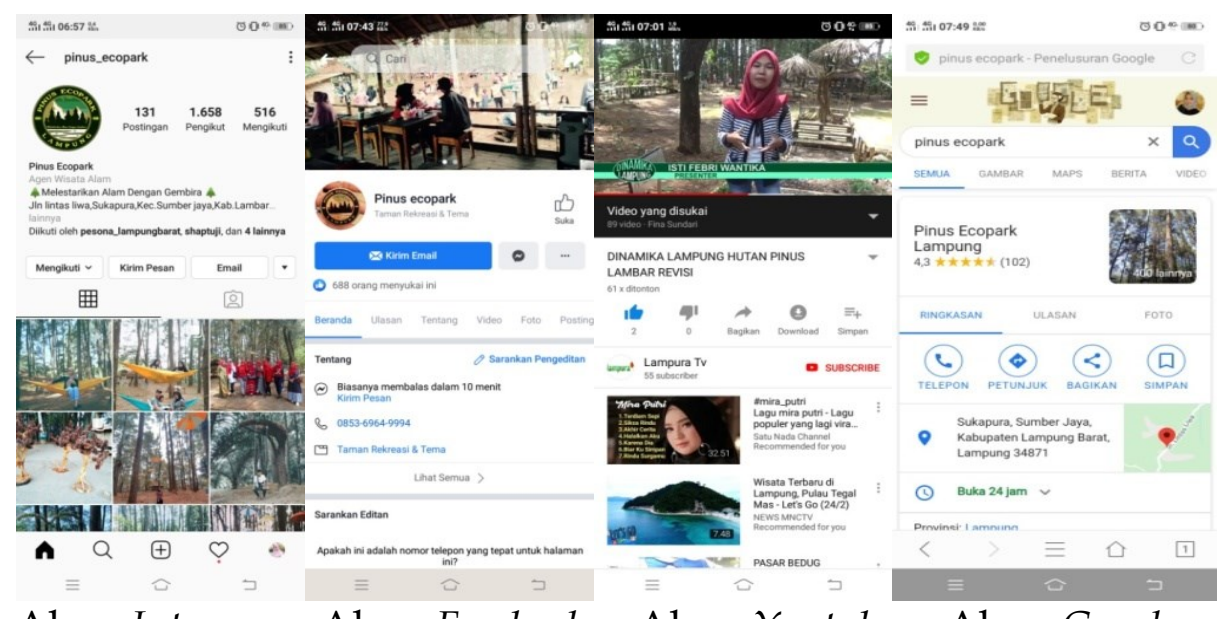

Akun Intagram Akun Facebook Akun Youtube Akun Google

b. Penjualan Personal (personal selling)

Penjualan personal adalah bentuk promosi secara personal dengan presentasi lisan dalam suatu percakapan dengan calon pembeli. Dalam hal ini pengelola pernah melakukan penjualan personal dimana pengelola menawarkan langsung kepada masyarakat yang ada di sekitar dan juga pengunjung di dalam acara Even Rokok Djarum, Gudang Garam, Pelatihan dan Praktik Pembibitan Pinus, serta dalam acara Solidaritas Peduli Negeri yang di sponsori oleh Pinus Ecopark, dengan menginformasikan semua fasilitas yang ada di dalam wisata (Nopianto Pengelola Wisata, Wawancara (Sukapura: 23 November, 2019)).

Berikut ini gambar beberapa Even yang pernah dilakukan oleh Pengelola Wisata Pinus Ecopark: 


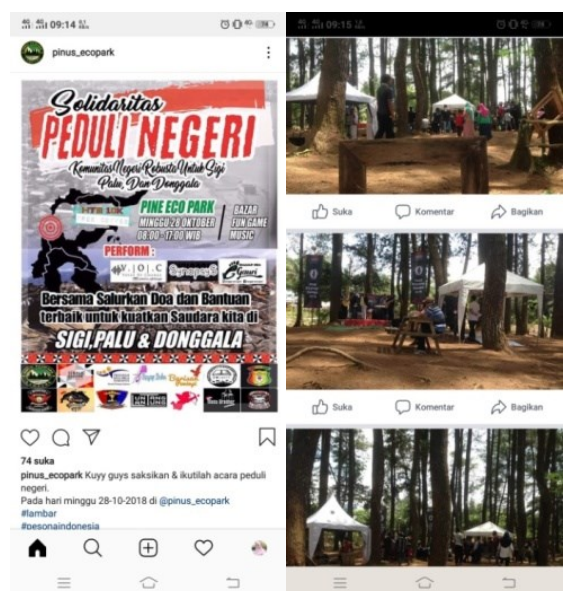

c. Promosi Penjualan (sales promotion)

Promosi penjualan adalah suatu bentuk promosi yang dilakukan secara insentif untuk menarik hasrat konsumen. Dalam hal ini pengelola wisata pinus ecopark pernah melakukan promosi penjualan dengan mengadakan tiket gratis selama 1 bulan diawal pembukaan wisata Pinus Ecopark (Arif Pengelola Wisata, Wawancara (Sukapura: 23 November, 2019)).

d. Hubungan Masyarakat (Public relation)

Hubungan masyarakat merupakan komunikasi non personal yang dilakukan untuk mempengaruhi dan mengubah opini publik seluas-luasnya, guna menciptakan citra yang baik. Dalam hal ini pengelola wisata pinus Ecopark perlu melakukan kerjasama yang baik dengan Pemerintah Daerah, dan juga Dinas Kepemudaan Olahraga dan Pariwisata Kabupaten Lampung Barat, guna menjalin hubungan internal yang baik (Dadang, Ketua HKM, Wawancara (Sukapura: 23 November, 2019)). 
e. Pemasaran Langsung (direct marketing)

Pemasaran langsung adalah komunikasi langsung dengan pelanggan yang diincar secara khusus untuk memperoleh tanggapan langsung. Dalam hal ini pengelola wisata pernah melakukan pemasaran langsung kepada calon pelanggan yang diincar yaitu pengunjung yang ingin melakukan prewedding, sehingga di wisata pinus Ecopark membuka objek yang bisa digunakan untuk Prewedding dengan biaya yang terjangkau mulai dari Rp 150.000-, hingga Rp 200.000-, (Johari Pengelola Wisata, Wawancara (Sukapura: 23 November, 2019)).

Berikut ini contoh gambar Prewedding yang pernah ada di wisata Pinus Ecopark:

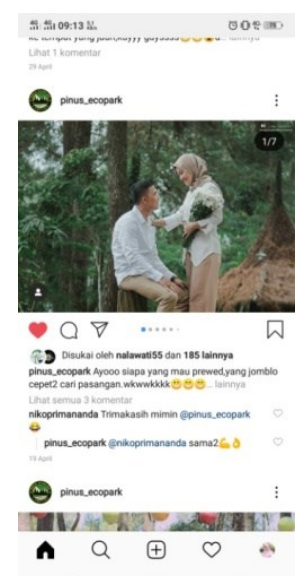

Dalam melakukan pengembangan Wisata Pinus Ecopark pengelola wisata mengajukan proposal kepada Dinas Kepemudaaan Olahraga dan Pariwisata Kabupaten Lampung Barat untuk menjalin kerjasama secara langsung dalam proses pengembangan Wisata, guna memperbaiki, memperbaharui, dan menambah fasilitas-fasilitas yang ada, seperti penambahan Gazebo, Perbaikan jalan menggunakan paping yang dapat menyerap air, Perbaikan taman bermain anak, penambahan Spot foto, penambahan Rumah Pohon, Penambahan Kamar kecil/WC, perbaikan saluran air, dll. Hal ini juga ditujukan guna meningkatkan jumlah 
kunjungan wisatawan, sehingga jumlah pengunjung semakin meningkat dan wisata Pinus Ecopark dapat dikenal oleh khalayak luas. Selain itu diharapkan dengan adanya wisata pinus ecopark ini dapat meningkatkan pertumbuhan ekonomi, Meningkatkan kesejahteraan masyarakat, membantu mengatasi pengangguran dan Melestarikan alam, lingkungan, dan sumber daya yang ada (Dadang, Ketua HKM, Wawancara (Sukapura: 23 November, 2019)).

Berdasarkan hasil Survey dengan 5 pengelola wisata, rata-rata jumlah pengunjung wisata Pinus Ecopark setiap bulannya selalu meningkat. Berikut data pengunjung wisata Pinus Ecopark pada tahun 2018 dan 2019:

Tabel 2.1 Jumlah Pendapatan Wisata Pinus Ecopark

\begin{tabular}{|l|c|c|}
\hline \multirow{2}{*}{ Bulan } & \multicolumn{2}{|c|}{ Tahun } \\
\cline { 2 - 3 } & $\mathbf{2 0 1 8}$ & $\mathbf{2 0 1 9}$ \\
\hline Januari & 408 & 1272 \\
\hline Februari & 600 & 1056 \\
\hline Maret & 648 & 1128 \\
\hline April & 744 & 1200 \\
\hline Mei & 696 & 1320 \\
\hline Juni & 792 & 1512 \\
\hline Juli & 1248 & 1560 \\
\hline Agustus & 1200 & 1680 \\
\hline September & 960 & 1728 \\
\hline Oktober & 1080 & 1763 \\
\hline Nopember & 1176 & 1821 \\
\hline Desember & 1200 & \\
\hline
\end{tabular}

Sumber: Hasil Wawancara dengan Pengelola Wisata Pinus Ecopark, 2019.

Data diatas menunjukan bahwa pengunjung wisata pinus ecopark rata-rata mengalami peningkatan setiap bulannya. Terlihat jumlah pengunjung pada bulan Januari hingga bulan Maret tahun 2018 terus mengalami peningkatan. Namun pada bulan Mei mengalami penurunan. Dan mengalami peningkat lagi pada bulan Juni dan Juli. Tetapi pada bulan Agustus mengalami penurunan hingga September, kemudian terus meningkat pada bulan Oktober hingga Januari 2019. Tetapi pada bulan 
Februari 2019 mengalami penurunan. Dan pada bulan Maret mengalami peningkatan terus menerus hingga bulan November 2019.

Dalam penelitian ini peneliti juga mengadakan wawancara dengan Pengunjung Wisata Pinus Ecopark yang pernah melakukan Kunjungan hanya satu kali dan tidak kembali berkunjung, yang lebih dari dua kali serta yang sedang berkunjung ke Wisata Pinus Ecopark.

Berikut adalah gambar-gambar spot foto yang sudah tidak ada lagi di lokasi wisata Pinus Ecopark:
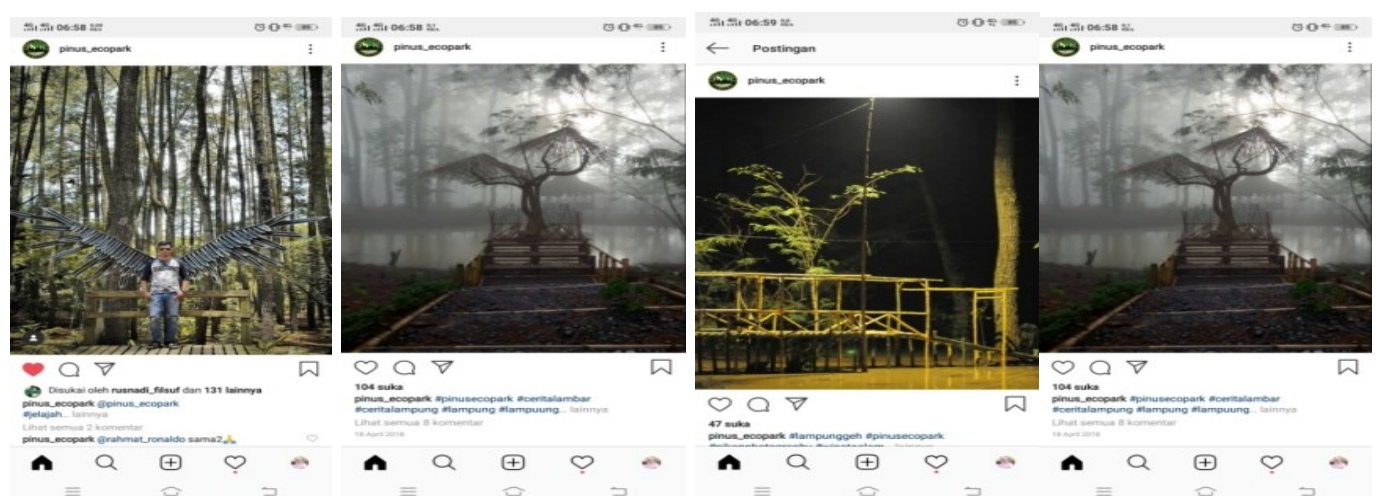

Menurut Bapak Andi ia pernah berkunjung ke Wisata Pinus Ecopark lebih dari dua kali, beliau mengatakan bahwa ia mengetahui wisata pinus ecopark melalui media sosial yaitu Instagram, menurutnya wisata pinus ecopark sangat menarik, nyaman, sejuk dan terjangkau, sehingga ia tertarik untuk berwisata ke wisata pinus ecopark. “Terakait dengan ketidaksesuaian gambar dalam media sosial dengan realita yang ada itu hanyalah hal biasa, karena spot-spot foto itu tidak semuanya bisa tahan lama, adapun yang di upload di instagram dan tidak sesuai, itu hanya foto-foto lama yang menunjukan kondisi pada waktu itu, tidak semua foto yang di upload itu tidak sesuai, sehingga menurut saya itu tidak ada unsur penipuan dan lainnya", ujar Bapak Andi. Namun menurut Bapak Andi memang ada beberapa hal yang perlu dibenahi di dalam wisata pinus ecopark seperti fasilitas yang ada masih kurang memadai, jembatan yang terbuat dari bambu itu sangat licin jika terkena 
hujan, dan juga sudah mulai rapuh, sehingga berbahaya (Andi, Wawancara (Sukapura: 23 November, 2019)).

Bapak Krisdianto yang pernah berlibur ke Wisata Pinus Ecopark lebih dari dua kali, Beliau juga mengatakan bahwa ia mengetahui wisata Pinus Ecopark ini melalui media sosial, dengan rasa penasaran yang tinggi ia pun berkunjung ke wisata tersebut. Dan menurut Bapak Krisdianto wisata Pinus Ecopark sangat menarik baginya, udara yang sejuk, dan nyaman membuat hati tenang, sehingganya beliau tertarik untuk kembali dan kembali lagi ke lokasi wisata. Terkait dengan gambar yang di upload di media sosial yang sudah tidak ada lagi di lokasi wisata, beliau menyimpulkan bahwa spot-spot foto itu tidak akan tahan lama, apa lagi jika terkena hujan secara terus menerus atau panas secara terus menerus, maka spot-spot foto tersebut akan mudah rusak. Jadi ketika pengelola meng-upload gambarnya pada waktu itu masih ada berarti beliau hanya menunjukan kondisi pada waktu itu, dan itu tidak termasuk kedalam unsur penipuan. Namun Bapak Krisdianto juga mengatakan beberapa kritik dan saran terkait wisata pinus ecopark, dimana di dalam wisata pinus ecopark hanya terdapat kantin yang menjual makanan ringan saja, belum terdapat makanan berat seperti nasi, pecel, dan sejenisnya. Sehingga pengunjung harus menahan lapar ketika di dalam lokasi wisata (Krisdianto, Wawancara (Sukapura: 23 November, 2019)).

Bapak Eko Prasetio bersama istri dan anaknya perempuan yang masih kecil, yang sering sekali berlibur ke Wisata Pinus Ecopark bahkan hampir setiap minggu, beliau mengetahui wisata Pinus Ecopark melalui Facebook. Beliau mengatakan wisata Pinus Ecopark sangat nyaman untuk dikunjungi, bahkan biaya parkir, tiket masuk juga sangat terjangkau, dengan udara yang sejuk, pemandangan pinus yang indah, dan banyak permainan anak di dalamnya. Terkait dengan foto yang ada di facebook ternyata tidak ada lagi di lokasi beliau merasa kecawa pada awalnya, tetapi ketika terus 
dinikmati suasana dan keindahan hutan pinus yang ada membuat beliau merasa nyaman dan tertarik untuk terus kembali berkunjung (Eko Prasetio, Pengunjung Wisata, Wawancara (Sukapura: 23 November, 2019)).

Feri Sandewo sering sekali berlibur ke wisata pinus Ecopark sekitar delapan kali lebih, ia mengetahui wisata ini melalui berbagai macam media sosial, seperti Instagram, Facebook, Google, bahkan ia pernah melihat dari Lampung TV. Tujuan feri datang ke lokasi wisata ini adalah untuk berlibur, ia sangat tertarik untuk kembali dan kembali lagi ke lokasi wisata karena menurutnya wisata pinus ini sangat menarik, nyaman, tenang, terjangkau, dan biaya cukup murah. Terkait dengan adanya ketidaksesuaian postingan gambar spot foto di akun media sosial dengan realita di lokasi, ia tidak mempermasalahkan hal tersebut. Menurut feri promosi yang dilakukan pengelola sudah cukup baik, tidak ada unsur penipuan sama sekali, dikarenakan pengelola selalu mengupload gambar sesuai dengan keadaan pada saat itu. Jika saat ini gambar tersebut sudah tidak ada maka hal wajar, karena sudah cukup lama, sehingga ada kemungkinan spot-spot foto tersebut rusak (Feri Sandewo, Wawancara (Sukapura: 23 November, 2019)).

Nita pernah berkunjung ke wisata pinus ecopark satu kali dan tidak kembali lagi berkunjung. Ia mengetahui wisata pinus tersebut melalui media sosial Instagram, Menurut Nita ia kurang tertarik dengan wisata pinus ecopark dikarenakan banyak fasilitas yang kurang memadai, dan juga spot-spot foto yang sudah hilang tidak ada lagi di lokasi, sehingganyaa ia merasa kecewa dengan postingan gambar di Instagram yang sudah tidak ada di lokasi tetapi masih tersimpan, kenapa tidak di perbaharui? Ujar Nita.

Eka Mugiarti adalah pengunjung wisata pinus Ecopark yang baru berkunjung satu kali, dan mengetahui lokasi wisata dari temannya, menurut eka wisata pinus ecopark lumayan bagus, dan suasanya nyaman. Namun menurut eka fasilitas yang ada di wisata pinus ecopark kurang memadai, tetapi eka tetap merasa senang berada di lokasi wisata dengan 
udara yang sejuk dan eka tertarik untuk kembali berlibur ke wisata pinus ecopark (Eka Mugiarti, Wawancara (Sukapura: 23 November, 2019)).

Cucu Purnama Sari adalah pengunjung wisata pinus ecopark, ia baru satu kali ini berkunjung ke wisata ini. Ia mengetahui wisata ini dari instagram. Dan karena rasa penasaran terhadap postingan gambar yang ada di instagram ia pun berkunjung ke lokasi, namun cucu merasa kecewa karena ketika ia sampai lokasi postingan gambar spot foto yang ia harapkan sudah tidak ada lagi dilokasi wisata, karena sudah rusak. Dan menurutnya itu termasuk kedalam unsur penipuan, seharusnya gambar tersebut di hapus saja dari media sosial agar tidak membuat kecewa, ujar cucu (Cucu Purnama Sari, Wawancara (Sukapura: 23 November, 2019)).

\section{G. ANALISIS STRATEGI PROMOSI PENGEMBANGAN WISATA PINUS ECOPARK MELALUI MEDIA SOSIAL DALAM PERSPEKTIF ETIKA BISNIS ISLAM}

Islam menekankan pentingnya penerapan etika bisnis Islami bagi marketer/pemasar muslim dalam kegiatan promosinya, sebagaimana Rasulullah SAW menerapkannya ketika beliau melakukan aktivitas dagang. Di antara perilaku beliau harus menjadi patokan bagi para marketer/pemasar muslim lainnya dalam melakukan bauran promosi di antaranya:

a. Kejujuran dan tidak menyembunyikan cacat produk. Kejujuran dalam memberikan keterangan terkait informasi produk secara jelas sangat dianjurkan dalam berpromosi agar tidak menimbulkan kesalahpahaman dan percekcokan. Dalam hal ini pada dasarnya pengelola wisata Pinus Ecopark telah menerapkan prinsip ini dengan postingan foto yang sesuai dengan kondisi sesungguhnya. 
b. Tidak Bersumpah Palsu. Melakukan sumpah palsu dalam berpromosi sangat dilarang dalam islam. Maka katakanlah yang sejujurnya, janganlah mudah untuk mengobral sumpah palsu terhadap konsumen. Dalam hal ini pengelola wisata Pinus Ecopark tidak melakukan sumpah palsu. Caption ditampilkan secara segerhana dan tidak dibesar-besarkan.

c. Tidak menjelek-jelekkan atau menjatuhkan produk saingan. Dalam islam dilarang untuk melakukan persaingan yang saling menjatuhkan. Melainkan saling bekerjasama dan saling bersinergi untuk dapat memenuhi kebutuhan konsumen sesuai dengan keinginannya. Dalam hal ini pengelola wisata Pinus Ecopark tidak menjelek-jelekan tempat wisata lainnya dan tidak saling menjatuhkan. Justru dalam hal ini pengelola saling bersinergi dengan pengelola wisata lain untuk sama-sama meningkatkan obyek wisata yang berada di lampung barat.

Pada hakikatnya promosi dalam perspektif etika bisnis islam adalah kegiatan promosi yang berlandaskan pada Al-Qur'an dan As-Sunnah. Sehingga kegiatan promosi yang dilakukan dapat membawa keberkahan di dunia dan akhirat. Karena berbisnis bukan hanya mencari keuntungan, tetapi itu harus diniatkan sebagai ibadah kita kepada Allah SWT, dengan menerapkan prinsip-prinsip etika bisnis islam yaitu, Keesaan (Tauhid), Keseimbangan (Adil), Kehendak bebas, Bertanggung jawab, dan Kejujuran.

Tauhid adalah mengesakan Allah, berserah diri kepada Allah, dan menjalankan segala perintah Allah serta menjauhi larangan Allah. Manusia sebagai khalifah di bumi diberikan kebebasan dalam melakukan segala sesuatu, maka segala sesuatu yang dilakukan memiliki batasan-batasan dan selalu berhubungan dengan Allah. Dalam hal ini pengelola wisata pinus ecopark memiliki kebebasan untuk melakukan pengembangan wisata pinus ecopark, dengan batasan-batasan yaitu tetap menjaga alam, tidak 
merusak lingkungan, bertujuan untuk kemaslahatan, dan untuk pemberdayaan masyarakat sekitar, sehingga dapat menciptakan lapangan pekerjaan guna mengurangi pengangguran.

Hal ini berarti bahwa setiap kegiatan yang dilakukan baik dalam bidang ekonomi, bisnis, ataupun yang lainnya, harus dilakukan secara seimbang dan adil terhadap semua pihak, baik yang terlibat secara langsung maupun tidak langsung. Agar semua pihak mendapatkan hak dan kewajibannya secara adil, dan tidak ada yang terdhalimi. Dalam hal ini pengelola wisata pinus ecopark juga selalu menjaga lingkungan, seperti menjaga kebersihan lokasi wisata, memisahkan sampah-sampah organik dan non-organik, memberikan pelayanan dengan baik, dan ramah terhadap pengunjung wisata, agar para pengunjung merasa aman dan nyaman selama berada di lokasi wisata.

Kebebasan merupakan bagian penting dalam nilai etika bisnis islam, tetapi dalam ajaran islam yang dimaksut dengan kebebasan adalah kebebasan yang bertanggung jawab dan tidak merugikan orang lain. Dimana segala sesuatu dalam islam selalu berdasarkan ketentuan Allah dan Rasul yang ada pada Al-Quran dan As-Sunah. Dalam hal ini pengelola wisata pinus ecopark sudah terdaftar dalam asuransi, sehingga pengelola dapat menjamin kesehatan pengunjung selama berada di lokasi wisata, seperti misalnya terjadi kecelakaan saat sedang bermain flying fox, maka pengobatan akan ditanggung oleh pengelola wisata pinus ecopark.

Tanggung jawab secara etika bisnis islam adalah perilaku seseorang dalam melakukan aktivitas bisnis dengan penuh rasa tanggung jawab dimana ia selalu merasa bahwa dirinya selalu diawasi oleh Allah dalam melakukan segala aktivitasnya, dan selalu memiliki rasa bahwa usaha yang dilakukan sekarang, kelak akan dimintai pertanggung jawaban diakhirat, apakah usaha yang dilakukan baik atau tidak, merugikan oranglain atau tidak, serta memberikan informasi secara benar atau tidak, dan 
mengandung unsur penipuan atau tidak. Dalam hal ini pengelola wisata pinus ecopark melakukan kegiatan promosi sesuai dengan etika bisnis islam, beliau mempromosikan wisata sesuai pada kenyataan yang ada, tidak ada unsur penipuan di dalamnya.

Kejujuran merupakan sifat dari pelaku bisnis yang harus ada dan harus dimiliki, karena sifat jujur merupakan kunci utama untuk mendapatkan kepercayaan dari orang lain. Kejujuran juga berkaitan dengan Tauhid, dengan keadilan, dengan kebebasan berkehendak, dan berkaitan dengan tanggung jawab. Ketika pelaku bisnis tidak memiliki sifat jujur maka sama saja ia tidak mengesakan Allah, tidak berbuat adil, memilih kehendak yang salah, sehingga ia harus mempertanggungjawabkan ketidakjujurannya terhadap Allah kelak di Akhirat. Dalam hal ini pengelola wisata melakukan kegiatan promosi dengan jujur. Tidak menyembunyikan cacat produk dan tidak pula mengobral sumpah dalam kegiatan promosi yang dilakukan.

Dari hasil wawancara dengan pengunjung wisata Pinus Ecopark dapat disimpulkan bahwa kebanyakan pengunjung tidak merasa tertipu, dan tidak merasa kecewa terhadap postingan gambar spot foto di media sosial yang sudah tidak ada lagi di lokasi wisata. Seperti Bapak Andi, Bapak Krisdianto, Bapak Eko Prasetio, dan Feri Sandewo, mereka samasama tertarik dengan wisata Pinus Ecopark, yang menurut mereka bisa membuat nyaman, terasa sejuk, tampak indah, dan terjangkau. Sehingga mereka ingin kembali dan kembaki lagi ke lokasi wisata. Mereka juga menyatakan bahwa tidak ada unsur penipuan atau ketidakjujuran pengelola dalam melakukan promosi.

Berbeda dengan pendapat Nita dan Cucu purnama sari yang menyatakan bahwa mereka kecewa dengan postingan gambar spot foto yang sudah lama tetapi masih saja ada di media sosial dan tidak di 
perbaharui, sehingga membuat mereka tidak ingin untuk kembali lagi ke lokasi wisata.

Berbeda pula dengan Eka mugiarti yang hanya mengetahui lokasi wisata Pinus Ecopark melalui salah seorang temannya, namun eka justru merasa senang berada di lokasi wisata pinus ecopark, dan tertarik untuk kembali lagi.

\section{H. SIMPULAN}

Berdasarkan hasil penelitian dan pembahasan dalam skripsi ini, maka dapat disimpulkan bahwa strategi promosi pengembangan Wisata Pinus Ecopark yang digunakan oleh pengelola wisata yaitu melalui berbagai variabel promosi diantaranya yaitu periklanan, penjualan personal, promosi penjualan, hubungan masyarakat, dan pemasaran langsung. Dimana dalam melakukan periklanan pengelola menggunakan berbagai media seperti media sosial, diantaranya yaitu Facebook, Instagram, Youtube, Google, Dan juga menggunakan media cetak seperti buku-buku wisata yang diterbitkan oleh Dinas Kepemudaan Olahraga dan Pariwisata Lampung Barat, dan juga Banner yang di pajang di area Wisata Pinus Ecopark, Serta melalui media elektronik seperti Rajawali TV (RTV), TVRI Lampung, Indosiar, dan juga Lampung TV.

Dalam melakukan kegiatan promosi pengelola wisata pinus ecopark telah melakukan promosi sesuai dengan etika bisnis islam, namun ada hal yang menjadi permasalahan dan percekcokan yang menyebabkan kesalahpahaman diantara postingan pengelola wisata dengan pengunjung wisata, dimana postingan gambar spot foto yang sudah lama tidak di perbaharui oleh pengelola wisata, sehingga membuat beberapa pengunjung menjadi kecewa karena kesalahpahaman tersebut. 


\section{DAFTAR PUSTAKA}

Abdurrahman, Nana Herdiana. Manajemen Strategi Pemasaran. Bandung: CV Pustaka Setia, 2015.

Abidin, Zainal, dan Hutami P. Puspitasari. Mina Bisnis Ikan Cupang. Malang: UB Press, 2018.

Astuti, Marhanani Tri, dan Any Ariani Noor. "Daya Tarik Morotai Sebagai Destinasi Wisata Sejarah Dan Bahari." Jurnal Kepariwisataan Indonesia Vol. 11 No. 1 Juni (2016).

Atiko, Gita, Ratih Hasanah Sudrajat, dan Kharisma Nasionalita. "Analisis Strategi Promosi Pariwisata Melalui Media Sosial Oleh Kementerian Pariwisata Ri (Studi Deskriptif Pada Akun Instagram @Indtravel)." Jurnal Sosioteknologi Vol. 15, No 3, Desember (2016).

Bungin, Burhan. Metodologi Penelitian Sosial dan Ekonomi. Jakarta: Kencana, 2013.

Cahya Nurhadi, Febrianti Dwi, Mardiyono, dan Stefanus Pani Rengu. "Strategi Pengembangan Pariwisata Oleh Pemerintah Daerah Terhadap Pendapatan Asli Daerah (Studi Pada Dinas Pemuda, Olahraga, Kebudayaan Dan Pariwisata Kabupaten Mojokero)." Jurnal Administrasi Publik (JAP) Vol. 2, No. 2 (t.t.).

Djakfar, Muhammad. Etika Bisnis Menangkap Spirit Ajaran Langit dan Pesan Moral Ajaran Bumi. Jakarta: Penebar Plus, 2012.

Fitriana, Evi. "Strategi Pengembangan Taman Wisata Kum Kum Sebagai Wisata Edukasi Di Kota Palangkaraya." Jurnal Pendidikan Geografi Nomor 2, Juni (2018).

Hadi, Sutrisno. Metodologi Penelitian Research 1. Yokyakarta: Yayasan Penerbitan Fakultas Psikologi UGM, 1981.

Hidayat, Marceilla. "Strategi Perencanaan Dan Pengembangan Objek Wisata (Studi Kasus Pantai Pangandaran Kabupaten Ciamis Jawa Barat)." Tourism and Hospitality Essentials (THE) Journal Vol. I, No. 1 (2011).

Isdarmanto. Dasar-Dasar Kepariwisataan dan Pengelolaan Destinasi Pariwisata. Yogyakarta: Gerbang Media Aksara, 2017.

Kuncoro, Mudrajad. Metode Riset Untuk Bisnis Dan Ekonomi. Jakarta: Erlangga, 2003.

Mustofa, Imam. Fiqih Muamalah Kontemporer. Jakarta: Rajawali Pers, 2016.

Nata, Abuddin. Akhlak Tasawuf dan Karakter Mulia. Jakarta: Rajawali Pers, 2015 